if the positive date of objects of clay, iron and bronze be demanded, the answer must allow of a margin of error of anything up to threo thousand years. Of the minor arts of the historic period nothing is known at all; between 'prehistoric' and historic thero is no correlation, and so far as cultural history is concerned, 'prehistory' may be said to continue to the sixteenth century A.D.

After such a scathing indictment of wasted oppor. tunity, almost any recommendation would probably bo acceptable; but Sir Leonard, while indicating where and on what considerations operations in the field might be extended, wisely counsels that in present conditions increased expenditure on excava. tion would bo harmful rather than a benefit, until the work of the Department has been placed on a sound basis.

Except in so far as they are directed to ensure the increase of archrological knowledge in accordance with scientific method, Sir Leonard Woolley's recommendations in detail are tho concern of the administrative authorities of the Government of India, rather than of interest to archaologists at large. In view of Sir Leonard's long experience and his wide and profound knowledge of the problems of archa. logical exploration, it may bo accopted that his recommendations are such as to secure that the archæological staff shall bo fully efficient to carry on excavations on sites chosen for their anticipated possibilities of advancing knowledge, in co-operation with a museum service also working to that end, the service being equipped and organized in such a manner as to afford facilities for the training of future officers ; while the curtailment of unnecessary and wasteful activities, especially in misdirected conservation, will avoid excessive increase in the Department's budget. One recommendation to which heartfelt welcome will bo given outside India is that for the appointment of two specially qualified officers to deal with the earlier prehistoric period, namely, the stone ages.

Of wider general interest are the sections of the report which deal with excavation by bodies other than the Survey and by organizations from outside. Müch disappointment has been expressed in ono quarter and another that enlargement of the provisions of the Antiquities Law has failed to attract nonofficial excavation. Sir Leonard rightly points out. that the responsibility is to be laid on a law which, liberal as it is in form, allows no prescriptive right. to the excavator of a share in the finds, but leaves this open as a matter of interpretation. This and other matters, including training in excavation for officials by reservation of the right of the Department to attach one of its officers to an expedition's personnel, are covered by amendments to tho law here suggested. Provision for early publication is also mado ; while tho importanco of early publication in accessible and suitable form at a reasonable price by the Survey itsolf is strongly urged.

\title{
THE INFORMATIVE CONTENT OF EDUCATION
}

\begin{abstract}
$\mathrm{T}$ HE second report of the Committee of the British Association appointed to consider the gaps in the content of education to which MIr. H. G. Wells directed attention in his presidential address to Section I (Education) at Nottingham was presented at the Lundee meeting. The first report revealed $a$ general agreement that Mr. Wells's suggestions were too wide in scope and too advanced for the capacity of the pupils concerned. There were, however, differences of opinion, and the present report shows in answer to inquiries by the committee the results attained by school-teachers in the studies commended by Mr. Wells. He, of course, when addressing tho Association, used grown-up language suitable for his audience but not for children of the age of 7-11 years. It is clear now that much of the information he wished to see taught can be learnt and might be acquired with advantage by young children.

The results here noted and tabulated by school. teachers are very promising, in view of the small portion of time available for such teaching, and it is really important. We are not getting at present anything like the return we are entitled to expect from the vast sums spent yearly on education, and this criticism applies particularly to science and such allied subjects as geography, which reaches out on one side to history and on the other to scientific research. Though experts may differ as to the way in which geography should be taught, every one will agree that small children should learn to understand and use maps, so that they can find their own way about with confidence and help others, when questioned, by intelligent replies.
\end{abstract}

Nature study, so far, has had but poor results, though a host of useful books are available. One thing is evident : young children must, whenover it is possible, have the actual objects used before them. The plot of ground designed by one school for study is an excellent idea. Here "the course is recreative rather than formal, but at the same time special studies are made whero accuracy is insisted on". The comment shows the survival of tho view that education must be carefully dissociated from amusement. Biology for tho young is not easy, and is perhaps best. taken in connexion with personal hygiene. Many friends of education have long been convinced that too much is attempted in the curriculum of to-day. Thus the "Civics Course" of one school reminds us that in Russia this subject with a pronounced tinge of 'red' was forced on schoolmasters, who repudiated it and went back to teaching on the old lines. Here at least, in Mr. WVells's requirements, we are concerned with practical knowledge promoting good health and the pleasure and utility of good observation for all children. The juvenile standard of intelligence in this way in children in Great Britain is not equal to that shown by foreign children. Knowledge of other lands and ways of life is rightly emphasized. The sort of patriotism which declares that your own country is the only one which is right is out of date.

The juvenile sections of freo libraries should be a great help and more useful, as implying effort, than B.B.C. talks. In general, the schemes of work printed are excellent, but a pertinent question asked is : How can the teacher find time or opportunity to keep up with all this, especially when he is confronted with the very wide method of stimulus known as 
'encyclopædia work' practised in a London junior school? The observations on the junior schools note many omissions in science. Even if wo agree that somo of Mr. Wells's ideas are beyond young folks, some of the simpler work is disappointing; in elementary physiology, for example, questions about seeds and animals. Tho senior schools do not supply many records, but those given are elaborate enough to suggest the need for real refresher courses for teachers. Interest in science of somo sort may bo rezarded as universal. Unfortunately it is not, and whoro teachers lack interest they aro not likely to provide the stimulus which leads to permanent keenness in their pupils.

\section{EDUCATION AND INDUSTRY}

\begin{abstract}
$\mathrm{T}$ HE discussion on education as a preparation for industry which followed Dr. A. P. M. Fleming's presidential address on education for industry to Section I (Educational Science) of the British Association, delivered on August 31, was opened by a paper, read in his absence, by Mr. IV. O. Lester Smith, director of education of Manchester, who stressed the importanco of a sound general education and the significance of Hadow reorganization. Our educational neglect of the adolescent has led to wastage of human material. The wanton blow struck at the day continuation school clauses of the Fisher Act by the 'Geddes Axe' was probably the unkindest cut our educational system has ever suffered; it has prevented local authorities from making a satisfactory job of the youth problem.
\end{abstract}

Discussing the organization of technical education, Mr. Lester Smith referred to the value of regional co-operation and the necessity for a constant revision of the subject-matter of technical education to meet tho needs of a competitivo and scientific age. Although the Trades Union Congress adopted a cautious attitude to somo modest suggestions in the Spens report for the infusion of technical teaching into the later stages of tho secondary school curriculum, there aro signs of $\mathbf{a}$ chango in outlook. Employers aro more disposed to seo value in general education, and teachers are appreciating moro fully the additional interest which an occupational bias can give to the last stage of school life. There is no strong evidence, however, in tho post-graduate work in universities of $a$ desire to assist industry to grapple with new problems. Industry as a career is regarded as a side-line, and industry and commerce will continue to roly mainly for its personnol, both leaders and rank and file, upon the less academic institutions and schools administered by local authorities. Finally, Mr. Lester Smith referred to the importance of facilities for training technical teachers and providing for the adequate dissemination of knowledge of new processes or of the achievements of research.

Sir Richard Gregory described opportunities open to apprentices at Portsmouth dockyard, while Dr. K. Fisher, headmaster of Oundle School, referring to the criticism of public schools that they give their pupils no chance of contact with the rest of the youth of the country, suggested that compu sory national sorvice may remove that disability. Public schoolboys and other youths may thus become conscious of a common bond. Moreover, employers are increasingly anxious to find public schoolboys to enter their service.

The allied discussion on education in industry, which followed on September 1, was opened by Mr. J. D. Langmuir, who emphasized the responsibility and obligation of all who employ young workers to see that they have adequate practical and technical training to suit thoir abilities. The narrow specific workshop or office training should be provided by the employer, but the responsibility for technical training should be shared with those responsible for education. There is little or no organized and systematic workshop training in Scotland, and the position of technical education is equally unsatisfactory. There has been no co-operation between education and industry, and real progress in technical education is impossible in its absence and until employers tako moro intorest in both day-school and tochnical education.

After criticizing both Scottish day-school and technical education, Mr. Langmuir advocated a bolder policy of grading, which would givo the pupil free choico of a courso suitable for his occupational desires. A boy with an occupational objective is more likely to remain to obtain the certificate which would facilitate entrance to his chosen career. Education should bo less bookish; attempts to convert secondary schools into miniature universities resisted. Supporting the idea of the junior technical school, he pleaded for closer co-operation with industry on the lines of the Edinburgh continuation class scheme. He stressed the obligations of employers for technical education of young workers and the limitations of works schools, and he also discussed the possibilities of introducing day continuation classes. Beforo this is possible, he said, leaders of industry and commerce must recognize the importance of such education. In technical education we are far behind Belgium, Denmark and Germany, and the provision of a wellthought-out scheme of technical education for the rank and file of our workshops and commercial houses is long overdue.

A written communication by Mr. G. L. Darbyshire, of the London Midland and Scottish Railway, which was read by Dr. Fleming, described the methods of recruitment and qualifications required for engagement by that company, as well as the training arrangements, both internal and external. In addition to classes for.instruction in such special branches as block signalling, locomotive working, permanent way maintenance, etc., and lectures on special problems arranged internally, the staff are encouraged to proceed in further education. Films as well as departmental publications are used freely for instructional purposes.

Discussing part-time education outside the works, Principal J. Cameron Smail, of the Heriot Watt College, Edinburgh, reforred to the strain on individuals involved by part-time education in ovening classes, although the results have justified the method. The outstanding results achieved with day classes in the dockyard scheme, however, have shown the 